九州大学学術情報リポジトリ

Kyushu University Institutional Repository

\title{
Accumulation, Digestion and Excretion of Bloodmeal Protein during Feeding in Nymphal Haemaphysalis Zongicornis
}

Koh, Katsuki

Zoological Laboratory, Faculty of Agriculture, Kyushu University

Shiraishi, Satoshi

Zoological Laboratory, Faculty of Agriculture, Kyushu University

Uchida, Teruaki

Zoological Laboratory, Faculty of Agriculture, Kyushu University

https://doi.org/10.5109/23893

出版情報 : 九州大学大学院農学研究院紀要. 34 (1/2)，pp. 107-114，1989-11. Kyushu University バージョン：

権利関係 : 


\title{
Accumulation, Digestion and Excretion of Bloodmeal Protein during Feeding in Nymphal Haemaphysalis Zongicornis
}

\author{
Katsuki K oh, Satoshi Shiraishi* and Teru Aki Uchida \\ Zoological Laboratory, Faculty of Agriculture, \\ Kyushu University 46-06, Fukuoka 812, Japan
}

(Received June 29, 1989)

\begin{abstract}
Changes in the rate of accumulation, digestion and excretion of bloodmeal protein during feeding in nymphal Haemaphysalislongicornis were examined. During the first feeding phase, the rate of protein accumulation and digestion showed little increase, but the rate of protein excretion had a relatively large increase. During the second feeding phase, the rate of protein accumulation increased gradually during the first half of this phase, and rapidly during the second half. The rapid increase in the protein accumulation resulted from an increase in the accumulation rate rather than that in the ingestion rate. The highest rate of digestion and excretion was found during this phase. During the third feeding phase, the rate of protein ingestion and accumulation reached a maximum, but the rate of protein excretion was minimal. Active accumulation of protein during this phase was caused by actions of both increase in the ingestion rate and decline in the excretion rate. The rate of protein digestion reduced during this phase.
\end{abstract}

\section{INTRODUCTION}

Ticks stock nutrient reserves for survival past the larval stage, molting and egg production, and transmit rickettsia and protozoa to the host by means of feeding. Studies of tick feeding may elucidate important aspects of ticks' life cycles and transmission of tick borne pathogens.

Based on the rate of body weight gain, the feeding period of immature and female ixodids has been classified into three phases (Balashov, 1972). A more detailed study (Araman, 1979) has shown that the three phases each has a distinct rate of the bloodmeal accumulation and digestion. Changes in the rates relate to development of midgut epithelial cells (Raikhel, 1983 ; Coons et al., 1986). Moreover, feeding ixodids discharge also the undigested bloodmeal protein (Hamdy, 1973, 1977). Although excretion is concerned largely with the fate of the ingested bloodmeal, information on discharge of the undigested bloodmeal is still poor. An integrated study of accumulation, digestion and excretion of the bloodmeal is necessary to understand the feeding process of ixodids.

The purpose of our study was to examine changes in the rate of bloodmeal accumulation, digestion and excretion during feeding in nymphal Haemaphysalis longicornis, and to discuss development of the midgut function.

*To whom reprint requests should be addressed. 


\section{MATERIALS AND METHODS}

Tick source : Nymphs used were derived from adults collected on a pasture in the Kujii highland, Ōita Prefecture. Nymphs were fasted for 40 days and then released on both ears of the rabbit. Hair was removed from the right ear to make excreta collection easier. Individuals which attached within $5 \mathrm{hr}$ were used. The peak of detachment time was seen 84 to $96 \mathrm{hr}$ after attachment.

Collection of samples : Excreta discharged from 95 nymphs attached on the right ear were collected every $12 \mathrm{hr}$ until $84 \mathrm{hr}$ after attachment. Unfed nymphs and feeding nymphs picked off from the left ear at $12 \mathrm{hr}$ interval after attachment were weighed. The midgut was dissected out in the cold saline and promptly frozen by means of liquid nitrogen. Excreta and the midgut were stored at $-95^{\circ} \mathrm{C}$ until analysis.

Fractionation of excreta and the midgut : Fractionation of excreta was carried out basically according to the method described by Hamdy (1973). Excreta were dried in a desiccator at $4^{\circ} \mathrm{C}$ for $12 \mathrm{hr}$, weighed, and then homogenized in $0.5 \mathrm{ml}$ distilled water per $\mathrm{mg}$ excreta. The suspension was centrifuged for $20 \mathrm{~min}$ at $\mathbf{1 5 , 0 0 0} \mathrm{rpm}$, and the supematant containing protein was recovered. The precipitate containing guanine and hematin was washed twice with distilled water, treated with $0.1 \mathrm{M} \mathrm{HCl}$, and then centrifuged for $20 \mathrm{~min}$ at $15,000 \mathrm{rpm}$. The supernatant containing guanine was pipetted. The precipitate containing hematin was washed twice with $0.1 \mathrm{M} \mathrm{HCl}$ and dissolved in $0.1 \mathrm{M} \mathrm{NaOH}$.

The midgut was homogenized in $0.02 \mathrm{M}$ Tris- $\mathrm{HCl}$ buffer ( $\mathrm{pH} 7.5)$, the suspension was centrifuged for $10 \mathrm{~min}$ at $15,000 \mathrm{rpm}$, and the supernatant containing protein was recovered. The precipitate containing hematin was washed twice with the same buffer and dissolved in $0.1 \mathrm{M} \mathrm{NaOH}$. All homogenization and centrifugation were performed in the cold and at $4^{\circ} \mathrm{C}$, respectively.

Analytical methods : The quantity of protein was determined by the dye-binding method using commercially prepared dye reagent (Bio-Rad, CA, U. S. A.) with rabbit hemoglobin (Sigma) as a standard. Electrophoresis, SDS-PAGE, was done to separate the protein components, using acrylamide gradient (5-15\%) slab gel at a constant current $(30 \mathrm{~mA})$. After electrophoresis, the proteins were stained with Coomassie brilliant blue R250 (Katayama Chemical Industries Company, Osaka, Japan). Spectrophotometric scans of the gels were carried out to measure protein components using a densitometer (Shimadzu CS-930) at $560 \mathrm{~nm}$. The quantity of guanine was detemined spectrophotometrically in $0.1 \mathrm{M} \mathrm{HCl}$ at $248 \mathrm{~nm}$ (Beaven et al., 1955). The quantity of hematin was assayed by the pyridine hemochrome system (Falk, 1964), using hemin chloride (Sigma) as a standard and its millimoler extinction coefficient of 31.4 at $555.5 \mathrm{~nm}$.

Calculation : The quantity of protein accumulated in the midgut per $12 \mathrm{hr}(\mathrm{P})$ was obtained by the following equation :

$$
\mathrm{P}(\mu \mathrm{g} / 12 \mathrm{~h})=\mathrm{P}_{12 \mathrm{n}+12}-\mathrm{P}_{12 \mathrm{n}}
$$

where : 
$\mathrm{P}_{12 \mathrm{n}+12}=$ the quantity of protein in the midgut at $12 \mathrm{n}+12 \mathrm{hr}$

$\mathrm{P}_{12 \mathrm{n}}=$ the quantity of protein in the midgut at $12 \mathrm{n} \mathrm{hr}$

The quantity of hemoglobin digested per $12 \mathrm{hr}(\mathrm{H})$ was obtained by the following equation :

$$
\mathrm{H}(\mu \mathrm{g} / 12 \mathrm{~h})=\left(\mathrm{H}_{12 \mathrm{n}+12}-\mathrm{H}_{12 \mathrm{n}}+\mathrm{H}_{\mathrm{e}}\right) \times \frac{16,700}{632.8}
$$

where :

$\mathrm{H}_{12 \mathrm{n}+12}=$ the quantity of hematin in the midgut at $12 \mathrm{n}+12 \mathrm{hr}$

$\mathrm{H}_{12 \mathrm{n}}=$ the quantity of hematin in the midgut at $12 \mathrm{n} \mathrm{hr}$

$\mathrm{H}_{\mathrm{e}}=$ the quantity of hematin excreted during the interval between the times of these 2 samplings

$16,700=$ a molecular weight of hemoglobin subunit

$632.8=a$ molecular weight of hematin

Since hemoglobin is a major protein component of the blood protein, and tick protease digests hemoglobin much better than albumin (Bogin and Hadani, 1973 ; Akov et al.,1976), the quantity of digested hemoglobin was regarded as a greater part of protein digested. Consequently, the quantity of digested hemoglobin was employed as the representative of digested protein.

\section{RESULTS}

Body weight : The nymphal body weight remained unchanged during the initial 12 $\mathrm{hr}$, increased gradually until $48 \mathrm{hr}$, rapidly until $72 \mathrm{hr}$, and then most rapidly during the final $12 \mathrm{hr}$ (Table 1).

Table 1. Weight changes during feeding in nymphal H. longicornis.

\begin{tabular}{ccc}
\hline $\begin{array}{c}\text { Time after attachment } \\
\text { in hours }\end{array}$ & $\mathrm{N}$ & Body weight in mg* \\
\hline (Unfed) & 17 & 0.25 \\
$\mathbf{1 2}$ & 20 & 0.25 \\
$\mathbf{2 4}$ & 19 & 0.36 \\
$\mathbf{3 6}$ & 20 & 0.50 \\
$\mathbf{4 8}$ & 20 & 0.70 \\
$\mathbf{6 0}$ & 20 & 1.31 \\
$\mathbf{7 2}$ & 20 & 1.85 \\
$\mathbf{8 4}$ & 20 & 3.13 \\
\hline
\end{tabular}

* Values are means.

Excreta: The quantity of total excreta became large until $60 \mathrm{hr}$, and then decreased (Table 2). The excretion pattern of protein was similar to that of total excreta, because a greater part of excreta (56.7-99.2\%, average 84.7\%) was composed of protein. The guanine content continued to rise throughout the feeding period. The ratio of the hematin content to total excreta was conspicuously low during feeding. Hematin excretion was detected for the first time at $36 \mathrm{hr}$, and the quantity increased until $60 \mathrm{hr}$, and then declined. 
Table 2. Total excreta and its protein, guanine and hematin contents during feeding in nymphal H. longicomis.

\begin{tabular}{cccccc}
\hline $\begin{array}{c}\text { Time after } \\
\text { attachment } \\
\text { in hours }\end{array}$ & $\mathrm{N}$ & \multicolumn{1}{c}{ Total excreta* } & Protein* & Guanine* & Hematin* \\
\cline { 2 - 5 } & & $\mu \mathrm{g}$ & $\mu \mathrm{g}(\%)$ & $\mu \mathrm{g}(\%)$ & $\mu \mathrm{g}(\%)$ \\
\hline 12 & 95 & 12.6 & $7.2(56.7)$ & $0.85(6.7)$ & $0.00(0.00)$ \\
24 & 95 & 72.0 & $70.1(97.4)$ & $2.14(3.0)$ & $0.00(0.00)$ \\
36 & 95 & 210.7 & $195.6(92.8)$ & $5.13(2.4)$ & $0.16(0.08)$ \\
48 & 95 & 380.2 & $377.5(99.2)$ & $7.02(1.9)$ & $0.23(0.06)$ \\
60 & 95 & 533.3 & $483.8(90.7)$ & $12.99(2.4)$ & $0.29(0.05)$ \\
72 & 89 & 343.3 & $308.7(89.9)$ & $13.81(4.0)$ & $0.16(0.05)$ \\
84 & $88^{\dagger}$ & 142.3 & $95.0(66.8)$ & $19.84(14.0)$ & $0.10(0.07)$ \\
\hline
\end{tabular}

* Values are means.

'Decrease in sample size is due to detachment of engorged nymphs.

M idgut contents : The protein content increased slightly until $12 \mathrm{hr}$, gradually until $48 \mathrm{hr}$, rapidly until $72 \mathrm{hr}$, and then most rapidly during the final $12 \mathrm{hr}$ (Table 3). The hematin content elevated slightly until $24 \mathrm{hr}$, and then gradually until $84 \mathrm{hr}$. The rate of its increase tended to decline during the final $12 \mathrm{hr}$.

Table 3. Protein and hematin contents in the midgut during feeding in nymphal H. longicomis.

\begin{tabular}{cccc}
$\begin{array}{c}\text { Time after attachment } \\
\text { in hours }\end{array}$ & $\mathbf{N}$ & Protein in $\mu \mathrm{g}^{*}$ & Hematin in $\mu \mathbf{g}^{*}$ \\
& & & \\
\hline (Unfed) & 17 & 2.2 & 0.18 \\
12 & 20 & 2.9 & 0.20 \\
24 & 19 & 6.1 & 0.34 \\
36 & 20 & 15.9 & 1.18 \\
48 & 20 & 25.1 & 2.16 \\
60 & 20 & 178.7 & 4.29 \\
72 & 20 & 402.4 & 6.16 \\
84 & 20 & 1097.8 & 7.28 \\
\hline
\end{tabular}

* Values are means.

Protein components in excreta and the midgut : Protein components of excreta and the midgut contents were separated electrophoretically, and 2 major protein bands were detected in both samples (Table 4). The $\mathrm{Rf}$ value for each of the 2 proteins was identical to that of albumin or hemoglobin. Other protein bands were hardly observed in excreta during feeding. In excreta, the ratio of hemoglobin to total protein showed no marked change. In the midgut contents, the quantity of albumin was larger than that of hemoglobin in unfed nymphs : during feeding, the midgut contained other proteins besides albumin and hemoglobin until $48 \mathrm{hr}$. Out of them, three proteins had molecular weights of 27, 000, 41,000 and 47,500, respectively. At $60 \mathrm{hr}$ and over when the protein content sharply rose, the three proteins were no longer detected, and the ratio of hemoglobin to total protein was preserved. 
Table 4. Albumin and hemoglobin contents of total protein in excreta and the midgut during feeding in nymphal H. longicormis.

\begin{tabular}{|c|c|c|c|c|c|c|c|}
\hline \multirow{3}{*}{$\begin{array}{l}\text { Time after } \\
\text { attachment } \\
\text { in hours }\end{array}$} & \multicolumn{3}{|c|}{ Excreta } & \multicolumn{4}{|c|}{ Midgut } \\
\hline & \multirow{2}{*}{$\mathrm{N}$} & Albumin* & Hemoglobin* & \multirow{2}{*}{$\mathrm{N}$} & Albumin* & Hemoglobin* & \multirow{2}{*}{$\begin{array}{c}\text { Others* } \\
\mu \mathrm{g}(\%)^{\dagger}\end{array}$} \\
\hline & & $\mu \mathrm{g}(\%)^{\dagger}$ & $\mu \mathrm{g}(\%)^{\dagger}$ & & $\mu \mathrm{g}(\%)^{+}$ & $\mu \mathrm{g}(\%)^{\dagger}$ & \\
\hline (Unfed) & & & & 17 & $1.4(62.9)$ & $0.7 \quad(32.4)$ & - \\
\hline 12 & 95 & $2.5 \quad(35.3)$ & $4.4 \quad(61.8)$ & 20 & $1.1(37.4)$ & $1.2(41.1)$ & $0.6 \quad(21.5)$ \\
\hline 24 & 95 & $18.0(25.7)$ & $49.7 \quad(70.9)$ & 19 & 1.1 (18.5) & $1.6(25.9)$ & $3.4 \quad(55.6)$ \\
\hline 36 & 95 & $56.1 \quad(28.7)$ & 133.2 (68.1) & 20 & $3.4 \quad(21.2)$ & $8.6(54.1)$ & 3.9 (24.7) \\
\hline 48 & 95 & 115.5 & $262.0 \quad(69.4)$ & 20 & $5.1(20.4)$ & $13.3(53.0)$ & $6.7 \quad(26.6)$ \\
\hline 60 & 95 & 150.5 & 333.3 (68.9) & 20 & $42.2 \quad(23.6)$ & $136.5 \quad(76.4)$ & - \\
\hline 72 & & $104.6(33.9)$ & $204.1 \quad(66.1)$ & 20 & $91.0 \quad(22.6)$ & $311.5 \quad(77.4)$ & \\
\hline 84 & $89 \ddagger$ & $34.4 \quad(36.2)$ & $57.6(60.6)$ & 20 & $292.0 \quad(26.6)$ & $805.8 \quad(73.4)$ & \\
\hline
\end{tabular}

* Values are means.

+ Ratio of each component to total protein.

$¥$ Decrease in sample size is due to detachment of engorged nymphs.

The fate of ingested protein : The quantity of protein ingested continued to increase throughout the feeding period with a temporary decline in the rate at $72 \mathrm{hr}$ (Table 5). The rate and ratio of protein accumulated were conspicuously low until 48 $\mathrm{hr}$, and then rose markedly with the maximum during the final $12 \mathrm{hr}$. The ratio of protein digested was low during feeding, and the rate heightened until $60 \mathrm{hr}$, and then decreased. The ratio of excreted protein remained elevated until $48 \mathrm{hr}$, and then declined with the minimum during the last $12 \mathrm{hr}$. This pattern was in a striking contrast to that for the ratio of protein accumulated.

Table 5. Ingested protein and its fate during feeding in nymphal $\mathbf{H}$. longicomis.

\begin{tabular}{ccccr}
\hline \multirow{2}{*}{$\begin{array}{c}\text { Time after } \\
\text { attachment } \\
\text { in hours }\end{array}$} & Ingested $*^{\dagger}$ & Accumulated* & Digested ${ }^{*}$ & Excreted $^{*}$ \\
\cline { 2 - 5 } & $\mu \mathrm{g}$ & $\mu \mathrm{g}(\%)$ & $\mu \mathrm{g}(\%)$ & $\mu \mathrm{g} \S(\%)$ \\
\hline 12 & 8.4 & $0.7(8.2)$ & $0.5(6.3)$ & $7.2(85.4)$ \\
24 & 77.1 & $3.2(4.2)$ & $3.7(4.8)$ & $70.1(91.0)$ \\
36 & 231.8 & $9.7(4.2)$ & $26.5(11.4)$ & $195.6(84.4)$ \\
48 & 418.6 & $9.2(2.2)$ & $31.9(7.6)$ & $377.5(90.2)$ \\
60 & 701.3 & $153.6(21.9)$ & $63.9(9.1)$ & $483.8(69.0)$ \\
72 & 586.1 & $223.8(38.2)$ & $53.7(9.2)$ & $308.7(52.7)$ \\
84 & 822.6 & $695.4(84.5)$ & $32.2(3.9)$ & $95.0(11.5)$ \\
\hline
\end{tabular}

* Values are means.

t Values concerned were calculated at total amounts of accumulated, digested and excreted proteins.

$\ddagger$ Values concerned were calculated at only an amount of hemoglobin.

$\S$ Values concerned are given here to facilitate a better understanding, being the same as in Table 2. 


\section{DISCUSSION}

This is the first integrated report on changes in the rate of accumulation, digestion and excretion of the bloodmeal protein during feeding in ixodids, and our discussion is focused on development of the midgut function in ixodids.

In general, the feeding period of ixodids was divided into the following three phases (Balashov, 1972 for Hyalomma asiaticum and Ixodes ricinus; Araman, 1979 for Rhipicephalus sanguineus), which are applicable to the case of nymphal H. Zongicornis.

The first feeding (preparatory) phase was defined as the state from attachment to $24 \mathrm{hr}$ later in nymphal H. Zongicornis. During this phase, the rates of body weight gain, and of protein accumulation and digestion showed little increase. However, the rate of protein excretion exhibited a relatively large increase, indicating that the nymph continuously ingested the bloodmeal to some extent. In female Hyalomma excavatum, proteolytic enzyme activity in the midgut is negligible in unfed ticks and rises with the onset of feeding (Bogin and Hadani, 1973). Moreover, undifferentiated epithelial cells of the midgut rapidly differentiate into digestive cells in the preparatory phase (Raikhel, 1983 for H. asiaticum). In this connection, the present study revealed that the digestion rate was low during this phase and became high during the next phase. Therefore, it is suggested that the formation of proteolytic enzymes and active differentiation into digestive cells in nymphal H. Zongicornis are induced by feeding stimuli during this phase.

The second feeding (growth) phase was defined as the state from $24 \mathrm{hr}$ to $72 \mathrm{hr}$ in the tick. The rates of both body weight gain and protein accumulation increased gradually during the first half of this phase and rapidly during the second half. The rapid increase of protein accumulation was due to the increased ratio of accumulated protein to ingested protein. Ixodids fill the midgut lumen with the enormous ingested bloodmeal during the final feeding stage (Chinery, 1964 for Haemaphysalis spinigera; Balashov, 1972 for H. asiaticum and I. ricinus; Raikhel 1983 for H. asiaticum; Agbede and Kemp, 1985 for Boophilus microplus; Coons et al., 1986 for Dermacentor variabilis). Accordingly, the abrupt increase of protein accumulation which occurred at the middle of this phase seems to mean the commencement of its accumulation in the midgut lumen in nymphal H. Zongicornis. In addition, the highest rate of digestion and the first discharge of hematin were found during the growth phase. At the active time of digestion during feeding, digestive cells filled with residual bodies (hematin) detach from the basement membrane in order to be replaced by new cells (Coons et al., 1986 for D. variabilis). Our results corresponded well with their histological findings. The reason why nymphal $\mathbf{H}$. Zongicornis accelerated the feeding rate during this phase, in spite of discharge of a large amount of protein, remains unsolved. In this connection, in female Dewnacentor andersoni, the quantity of protein in excreta differs between ticks fed on different hosts (Hamdy, 1977). Thus, the type of protein in the bloodmeal appears to be a key to elucidate the question.

The third feeding (expansion) phase was defined as the state of the final $12 \mathrm{hr}$ in nymphal $H$. Zongicornis. During this phase, the rate of body weight gain and protein ingestion reached a maximum, and most of ingested protein was accumulated in the midgut, and only small quantities were discharged as excreta. Consequently, active accumulation of protein during the final phase of feeding was caused by actions of both 
increase of the ingestion rate and decline of the excretion rate. The reduced activity of digestion at the final feeding stage has been observed in at least two ixodid species, and attributed to a great reduction or a cessation of lysosome production (Coons et al., 1986 for D.variabilis) and an occurrence of a proteolytic enzyme inhibitor in the midgut (Bogin and Hadani, 1973). In this respect, the present study indicated the relatively low rate of digestion during this phase. Accordingly, it is expected that the above-mentioned events occur also in nymphal $\mathbf{H}$. longicornis during this phase.

During the duration from attachment to the middle of the growth phase, unidentified proteins were detected in the midgut contents, but not in excreta. It is probable that these proteins are not intact proteins contained in the bloodmeal, but partially digested proteins and/or midgut structural proteins. Furthermore, the ratio of albumin and hemoglobin to total protein in excreta showed little changes. Therefore, in nymphal H. longicornis, proportions of the bloodmeal proteins might not change much during feeding. Such an assumption is supported by the finding in which there is no marked difference in uptake between plasma and red cells during feeding in immature and female B.microplus (Seifert et al., 1968).

The conclusion reached can be expressed as follows : during the first half of the feeding period, the quantity of protein accumulated in the midgut hardly increases on account of the high ratio of excretion, although the ingestion rate continues to increase ; during the second half, the quantity of accumulated protein becomes large in proportion to decrease of the excretion ratio because of the high ingestion rate.

\section{ACKNOWLEDGEMENTS}

We thank Dr. Y. Kawaguchi, Professor 0. Koga, Dr. N. Fujihara and Dr. T. Mōri, Faculty of Agriculture, Kyushu University, and Professor T. Omura, Faculty of Medicine, Kyushu University, for permission to use analytical instruments and for valuable suggestions ; and Professor E. W. Jameson, Jr., University of California, for comments on the manuscript. This work was supported in part by a Grant-in-Aid from the Ministry of Education, Science and Culture, Japan.

\section{REFERENCES}

Agbede, R. I. S. and D. H. Kemp 1985 Digestion in the cattle-tick Boophilus microplus: light microscope study of the gut cells in nymphs and females, Int. J.Parasitol., 15: 147-157

Akov, S., M. Samish and R. Galun 1976 Protease activity in female Ornithodoros tholozani ticks. Actatrop., 18: 37-52

Araman, S, F. 1979 Protein digestion and synthesis in ixodid females. In "Recent Advances in Acarology", Vol. 1, ed. by J. Rodriguesz, Academic Press, New York, pp. 385-395

Balashov, Yu. S. 1972 Bloodsucking ticks (Ixodoidea). Vectors of diseases of man and animals. Misc. Publ. Ent. Soc. Am., 8 : 161-376

Beaven, G. H., E. R. Holiday and E. A. Johnson 1955 Optical properties of nucleic acids and their components. In "The Nucleic Acids : Chemistry and Biology", Vol. 1, ed. by E. Chargaff and J. N. Davidson, Academic Press, New York, pp. 493-553

Bogin, E. and A. Hadani. 1973 Digestive enzymes in "hard ticks" (Ixodoidea, Ixodidae). I. Proteolytic enzyme activity in the gut of Hyalomma excavatum female ticks. $Z$. Parasitenkd., 41: $139-146$

Chinery, W.A. 1964 The mid-gut epithelium of the tick Haemaphysalis spinigera Neumann 1897. $J$. 
Med. Entomol., 1 : 206-212

Coons, L. B., R. Rosell-Davis and B. I. Tamowski 1986 Bloodmeal digestion in ticks. In "Morphology, Physiology, and Behavioral Biology of Ticks" ed. by J. R. Sauer and J. A. Hair, Ellis Horwood, West Sussex, pp. 248-279

Falk, J. E. 1964 Haems. In "Porphyrins and Metalloporphyrins: Their General, Physical and Coordination Chemistry, and Laboratory Methods", Elsevier, Amsterdam, pp. 181-188.

Hamdy, B. H. 1973 Biochemical and physiological studies of certain ticks (Ixodoidea). Cycle of nitrogenous excretion of Hyalommadromedarii Koch (Ixodidae). J. Med. Entomol., 10 : 345-348

Hamdy, B. H. 1977 Biochemical and physiological studies of certain ticks (Ixodoidea). Excretion during ixodid feeding. J. Med. Entomol., 14: 15-18

Raikhel, A. S. 1983 The intestine. In "An Atlas of Ixodid Tick Ultrastructure", transl. by A. S. Raikhel, ed. by A. S. Raikhel and H. Hoogstraal, Special Publ.Ent. Soc. Am., pp. 59-97

Seifert, G. W., P. H. Springell and R. J. Tatchell 1968 Radioactive studies on the feeding of larvae, nymphs, and adults of the cattle tick, Boophilus microplus (Canestrini). Parasitology, 58 : 415-430 